\title{
KRIZNA STANJA I PRIMJENA MJERA PRISILE U PSIHIJATRIJI ${ }^{1}$
}

Prof. dr. sc. Vesna Šendula Jengić, dr. med.*

Dr. sc. Sanja Katalinić, dr. med.**
UDK: 616.89

Ur.: 4. listopada 2017.

Pr.: 7. prosinca 2017.

Stručni rad

\section{Sažetak}

U radu se raspravlja o fenomenu agresivnosti i nasilja kod čovjeka, s posebnim osvrtom na duševno oboljele. Krizno stanje $i$ nasilno ponašanje ne događa se samo u psihijatriji. Ono se može dogoditi uvijek, a žrtva i počinitelj pod određenim okolnostima može biti svatko. Poznavanje multikauzalnosti $i$ kompleksnosti te individualnih okolinskih i situacijskih čimbenika koji dovode do nasilnog ponašanja imaju malu snagu predikcije. Statistički pokazatelji mogu skrivati lažno pozitivne i negativne rezultate, pri čemu pogreška procjene može drastično povećati rizik da se neko ponašanje dogodi ili dovesti do neopravdanog suspendiranja ljudskoga prava na slobodu.

Primjena prisile u psihijatriji nužna je samo iznimno i u ograničenom trajanju u situacijama kada se opasnim ponašanjem izravno ugrožava život $i$ zdravlje osobe ili okoline.

Pozitivna zakonska regulativa, posebice Zakon o zaštiti osoba s duševnim smetnjama (NN 76/2014) te Pravilnik o vrstama i načinu primjene mjera prisile prema osobama s težim duševnim smetnjama (NN 16/2015) dodatno štiti prava oboljelih i propisuje vrste i način primjene prisile kao i procedure za postupanje. Strukovna psihijatrijska društva dala su dodatne smjernice $i$ strategije za postupanje.

U radu se ističe potreba za boljim uvjetima, infrastrukturom i ljudskim resursima uz kontinuirano unaprjeđenje i evaluaciju kvalitete rada u psihijatriji. Zaključno, propituju se standardi i etička pitanja društva te širokog spektra aktivnosti, od

* Dr. sc. Vesna Šendula Jengić, dr. med., izvanredna profesorica Medicinskog fakulteta Sveučilišta u Rijeci, Ravnateljica Psihijatrijske bolnice Rab; vesna.sendula@gmail.com

** Dr. sc. Sanja Katalinić, dr. med, psihijatrica, Odjel za socijalnu psihijatriju Psihijatrijske bolnice Rab; katalinic69@yahoo.com

1 Ovaj rad je sufinancirala Hrvatska zaklada za znanost projektom IP-11-2013-2287 „Legal Status and Real Position of People with Mental Difficulties - Interdisciplinary Approach and European Perspectives" i Sveučilište u Rijeci potporama znanstvenim istraživanjima 13.08.1.3.02 "Interdisciplinarni pristup u istraživanju statusa osoba s duševnim smetnjama kroz prizmu konvencijskog prava". 
destigmatizacije, preko bolje dostupnosti usluga do standarda života $i$ socijalne uključenosti, koji posredno mogu dovesti do bitnog smanjenja nasilja u društvu.

Ključne riječi: agresivno ponašanje, prisila, ljudska prava, Psihijatrijska bolnica Rab.

\section{UVODNE NAPOMENE}

Prije rasprave o kriznim stanjima i prisili u psihijatriji potrebno je definirati nekoliko pojmova. Kada se spominje nasilno i agresivno ponašanje važno je imati na umu da pod određenim okolnostima svatko može postati agresivan. Dakle, iako je samo agresivno ponašanje najviše proučavano u etologiji u životinja, agresivnost je imanentna i čovjeku i ona se u određenim okolnostima može pretvoriti u autodestruktivno i /ili nasilno ponašanje pri čemu nasilnik, ali i žrtva može postati svatko.

Upravljanje vlastitom agresijom problem je i izazov za svakog čovjeka, te ovisi o nizu čimbenika: intrapsihičkim, interpersonalnim i okolinskim. Podrijetlo, uzroci i vrste agresivnosti odavno su predmetom proučavanja iz različitih perspektiva. ${ }^{2,3}$,

${ }^{4}$ Studije koje proučavaju fenomene agresije kod životinja uglavnom sagledavaju agresiju kao način opstanka vrste i odnosa unutar vrste, pri čemu agresija nema nužno negativni, nego adaptivni karakter, uključujući nagonske procese borbe ili bijega i u funkciji su preživljavanja vrste. Razvojem neuroznanosti, a osobito suvremenim, sve preciznijim metodama oslikavanja mozga, došlo se do određenih otkrića o neurobiološkim korelatima agresije. Tako se, između ostalog, oni vezuju za nukleus akumbens, prednji cingularni i orbitofrontalni korteks, kao i neke dublje strukture mozga, npr. amigdaloidne jezgre. Regulacija ponašanja i akcije u cilju razrješavanja konflikta, međutim, ne ovisi samo o tim jezgrama, nego i o neuralnim putevima i komunikaciji s višim, kortikalnim centrima putem, tzv. neurotransmiterskih sustava, pa čak i gena. Disregulacija bilo koje od tih razina može dovesti do socijalno neprikladnih obrazaca ponašanja. $5,6,7,8$

2 Farrington, D. P., Origins of Violent Behavior Over the Life Span (poglavlje 2.), u: Flannery, D. J. et al., The Cambridge Handbook of Violent Behavior and Aggression, Cambridge, Cambridge University Press, 2007.

3 Mattson, M. P. (ur.), Neurobiology of Aggression, Understanding and Preventing Violence, Totowa, New Jersey, Humana Press, 2003.

4 Fromm, E., The anatomy of human destructiveness, New York, Holt, Rinehart and Winston, 1973.

5 Davidson, R. J., et al., Dysfunction in the Neural Circuitry of Emotion Regulation - A Possible Prelude to Violence, Science, vol. 289., br. 5476., 2000., str. 591-94.

6 Frankle, W. G., et al., Brain Serotonin Transporter Distribution in Subjects With Impulsive Aggressivity: A Positron Emission Study With [ $11 \mathrm{C}] \mathrm{McN}$ 5652, American Journal of Psychiatry, vol. 162., br. 5., 2005., str. 915-23.

7 Van Elst, L. T., et al., Trimble, Affective aggression in patients with temporal lobe epilepsy: A quantitative MRI study of the amygdala, Brain, vol. 123., br. 2., 2000., str. 234-43.

8 Patrick, C. J., Psychophysiological correlates of aggression and violence: an integrative review, Philosophical Transactions of the Royal Society B: Biological Sciences, vol. 363., br. 1503., 
Biološki čimbenici u neprestanoj su interakciji sa psihosocijalnim i gotovo da se osim eksperimentalno ne mogu promatrati odvojeno nego u ozračju moralnih, kulturnih i društvenih prilika. Jedan od poznatijih modela istraživanja i tumačenja nasilja je ekološki. Ovaj model između ostaloga istražuje odnos između individualnih i kontekstualnih čimbenika. Pritom se razmatraju osobni, relacijski i čimbenici okoline, tj. uže i šire društvene zajednice koji mogu pridonijeti razvoju nasilnog ponašanja ili dovesti do senzibilizacije društva za nasilno ponašanje.

Kada se agresivnost izrazi nasilnim ponašanjem, tada je društvena reakcija očekivana. Svako počinjeno nasilje, osobito ono koje rezultira tragičnim događajem, refokusira promišljanja i stavove kliničara, pravnika i javnosti vrlo često u polarizirajućem pa čak i radikalnom smislu.

Svaka prisila i postupanje koje uskraćuje jedno od čovjekovih temeljnih prava, pravo na slobodu, može biti primijenjena samo ako za to postoje osnovani i zakonom propisani razlozi. U psihijatriji, pod prisilom bi se smatralo, osim prisilne hospitalizacije, i samo provođenje liječenja bez suglasnosti, ograničavanje kretanja, medikacija, ograničavanje komunikacije s trećim osobama, pa čak i institucionalno nametnuti kućni red. Konačno, svako prisiljavanje na ponašanja koja ugrožavaju autonomiju pojedinca i uzrokuju subjektivni distres, mogu utjecati na terapijski odnos i uspješnost liječenja. ${ }^{9}$

\section{DEFINICIJE POJMOVA}

Agresivno ponašanje je bilo koje prijeteće ponašanje, verbalno ili fizičko, a koje šteti osobi koja se ponaša agresivno, drugim osobama ili stvarima odnosno imovini. Ono ne mora nužno biti vezano uz psihijatrijsku dijagnozu iako je bitno veći rizik kod psihičkih poremećaja koji uključuju zloupotrebu i ovisnost o psihoaktivnim tvarima i kod poremećaja ličnosti.

Kriznim stanjem u psihijatriji možemo definirati sva ona stanja koja zahtijevaju hitnu intervenciju u cilju zaštite života i zdravlja bolesnika ili osoba u njegovoj okolini. Ova naizgled jednostavna definicija sadrži niz kompleksnih radnji i postupanja kojima se nastoji postići ponovna psihička ravnoteža i unutarnja harmonija pojedinca, uz moguće smanjenje patnje, ali i opasnosti da bi takvo stanje moglo proizvesti štetu za osobu i/ili okolinu. Zahtjevi za postupanje često su žurni i neodgodivi, pri čemu odgovor profesionalaca ponekad može biti i represivan.

Mjere prisile su sredstva $i$ metode fizičkog ograničavanja kretanja $i$ djelovanja bolesnika. Pravilnik o vrstama i načinu primjene mjera prisile prema osobi s težim duševnim smetnjama ${ }^{10}$ razlikuje dvije vrste mjera prisile: sputavanje i odvajanje. Sputavanje se odnosi na fiksaciju bolesnika različitim sredstvima (pojasevima, magnetnim trakama i sl.) čime se onemogućava njegovo fizičko kretanje, a odvajanje

2008., str. 2543-55.

9 Jaeger, M., Ketteler, D., et al., Informal coercion in acute inpatient setting - knowledge and attitudes held by mental health professionals, Psychiatric Research, vol. 220., br. 3., 2014., str. 1007-1011.

10 Pravilnik o vrstama i načinu primjene mjera prisile prema osobi s težim duševnim smetnjama, Narodne novine, br. 16/2015. 
podrazumijeva izoliranje bolesnika u zasebnu prostoriju, tzv. sobu za odvajanje. U većini zemalja je zakonski propisan način, trajanje i mjere ograničavanja kretanja bolesnika uz smjernice i protokole indikacija za sputavanje, kliničke procjene, postupanja i evaluacije tijekom trajanja ovih mjera. Mjere se primjenjuju samo $u$ situacijama kada niti jedna druga deeskalacijska tehnika ne daje rezultate, a život i zdravlje bolesnika i okoline su neposredno i izravno ugroženi. Trajanje mjera je samo onoliko koliko traje izravna fizička opasnost.

Prisilna hospitalizacija, odnosno smještaj bez pristanka i prisilno zadržavanje u psihijatrijskoj ustanovi također je jedna od vrsta primjene prisile, a provodi se isključivo u cilju zaštite života ili zdravlja dotične osobe ili drugih osoba. U Republici Hrvatskoj ova je mjera prisile regulirana Zakonom o zaštiti osoba $\mathrm{s}$ duševnim smetnjama (NN 76/14).

U širem smislu prisila bi bila ,subjektivni odgovor na određenu intervenciju, ${ }^{11}$, ali i ograničavanje osobnih izbora što rezultira fizičkim ili psihološkim distresom. ${ }^{12}$

\section{NASILJE I DUŠEVNA BOLEST - POSTOJI LI POVEZANOST?}

Vjekovna stigma determinirala je odnose u klasičnoj psihijatriji pa je nerazumijevanje patnje i potencijalno nepredvidivog ponašanja duševno bolesnih generiralo različite „preventivne“ aktivnosti zdravstvenih profesionalaca koje su uključivale i različite oblike sputavanja. Povijesno gledano, postupanje prema kriminalcima i duševno oboljelima ima puno zajedničkih obilježja. Demonizacija duševnih bolesnika zbog njihove anticipirane nepredvidivosti i opasnosti rezultirali su zastrašujućim postupanjima. ${ }^{13}, 14,15$ Gledajući unatrag kroz povijest bilo je nastojanja da se za duševno bolesne osiguraju vrlo dobri uvjeti liječenja, čime se potreba za prisilnim intervencijama bitno smanjivala. Poznate su psihijatrijske bolnice u kojima se promoviralo humano postupanje s duševnim bolesnicima još u 15. stoljeću u Španjolskoj, po čemu je ta zemlja i nazvana kolijevkom psihijatrije. Tek nekoliko stotina godina kasnije, tzv. „moralno liječenje“ u psihijatriji svesrdno je zastupao Philippe Pinel (1745.-1826.) kao jedan od prvih u Europi te Benjamin Rush (1745.1813.), Dorothea Dix (1802.-1887.) i Thomas S. Kirkbride (1809.-1883.) u 19. stoljeću u Americi. ${ }^{16}$

Fikcijska, medijska prezentacija, izražena osobito u filmskoj umjetnosti, sve više je prožeta nasiljem, a najintrigantnije i najviše zastrašujuće nasilje je ono koje se ne

11 Newton-Howes, G., Coercion in psychiatric care: where are we now, what do we know, where do we go?, The Psychiatrist, vol. 34., br. 6., 2010., str. 217-20.

12 Wynn, R., Psychiatric inpatients' experiences with restraint, Journal of Forensic Psychiatry \& Psychology, vol. 15., br. 1., 2004., str. 124-44.

13 Margetić, L., Opća povijest prava i države, Rijeka, Pravni fakultet Sveučilišta, Rijeka, 1998.

14 Šendula-Jengić, V., Bošković, G., Forenzički značaj drugih, težih duševnih smetnji, Zbornik Pravnog fakulteta Sveučilišta u Rijeci, vol. 22., br. 2., 2001., str. 635-654.

15 Peršić, N., Peršić-Brida, M., Povijesni razvoj psihijatrije, Socijalna psihijatrija, vol. 18., 1990., str. 237-281.

16 Šendula-Jengić, V., Juretić, I., Hodak, J., Psychiatric hospital: from asylums to centres for mind-body wellness, Collegium antropologicum, vol. 35., br. 4., 2011., str. 979-88. 
može predvidjeti, koje nema motiva ni razloga, kojeg je počinila „psihotična osoba“ ${ }^{17}$ Društvo je sklono fenomenima brutalnoga nasilničkog ponašanja dati atribut duševno bolesnog, jer se time odvaja od zastrašujućeg i neprihvatljivog. Pokazalo se, naime, da javnost percipira obrazloženo nasilje kao opravdano, a boji se onog nepredvidljivog, bezrazložnog nasilja koje se nedjeljivo povezuje s mentalnom bolešću. ${ }^{18}$

No, koliko je, i je li uopće, nasilno ponašanje povezano s mentalnom bolešću? Uvriježeno je mišljenje da povezanost nasilja i duševne bolesti postoji. Istraživanja na temu povezanosti duševne bolesti i nasilja daju kontroverzne rezultate. ${ }^{19}$ Uglavnom se radi o heterogenom fenomenu, koji se događa kao rezultat višestrukih, povezanih, ali i međusobno neovisnih čimbenika. Istraživanja su pokazala i da su incidencija i prevalencija nasilnog ponašanja kod osoba s duševnim smetnjama daleko manje od onih među psihički zdravima, a populacija duševno bolesnih češće je žrtva nasilja, odnosno daleko je veći rizik njihove viktimizacije u usporedbi s općom populacijom. ${ }^{20}$, ${ }^{21,22}$ Iskustvo viktimizacije može biti predisponirajući čimbenik za nasilno ponašanje. ${ }^{23}$

$\mathrm{Na}$ pojavu nasilnog ponašanja kod duševno oboljelih utječu razni biološki, psihodinamski i socijalni čimbenici. O snazi svakoga od njih, kao i njihovom međuodnosu, mišljenja stručne i znanstvene zajednice još nisu usuglašena niti jednoznačna. ${ }^{24}$

Iz ranije opisane multidimenzionalnosti i multikauzalnosti problema nasilja može se zaključiti da je odnos nasilja pojedinca i društva usko povezan, uzajaman i akcelerirajući. Iako zvuči paradoksalno, i zdravstveni radnici, čak i oni koji su izravno uključeni u procese dijagnostike i liječenja duševno oboljelih, mogu doprinijeti ovoj stigmi zbog nedostatka znanja, kompetencija i vještina, osobnih narcističkih potreba, neprofesionalnosti i neetičnosti, čija rezultanta mogu biti konfabulacije ili, rjeđe, „lovačke“ priče o duševno oboljelima. Nedostatak znanja o postupanju može biti jedan od rizičnih čimbenika nasilnog ponašanja i štetnih događaja. ${ }^{25}$

17 Horwitz, A. V., The Logic of Social Control, New York, Plenum Press, 1990.

18 Marzuk, P. M., Violence, Crime, and Mental Illness, Archives of General Psychiatry, vol. 53., br. 6., 1996., str. 481-6.

19 Friedman, Richard A, Violence and Mental Illness - How Strong is the Link?, New England Journal of Medicine, vol. 355., br. 20., 2006., str. 2064-66.

20 Hiday, V. A., et al., Criminal Victimization of Persons With Severe Mental Illness, Psychiatric Services, vol. 50., br. 1., 1999., str. 62-68.

21 Maniglio, R., Severe mental illness and criminal victimization: a systematic review, Acta Psychiatrica Scandinavica, vol. 119., br. 3., 2009., str. 180-91.

22 Dekker, J M., et al., Victimization of patients with severe psychiatric disorders: prevalence, risk factors, protective factors and consequences for mental health. A longitudinal study, BMC Public Health, vol. 10., br. 1., 2010., str. 687.

23 Hiday, V. A., The Social Context of Mental Illness and Violence, Journal of Health and Social Behavior, vol. 36., br. 2., 1995., str. 122-37.

24 Rueve, M. E., Welton, R. S., Violence and Mental Illness, Psychiatry, vol. 5., br. 5., 2008., str. 34-48.

25 Sartorius, N., Borba za duševno zdravlje, Zagreb, Profil multimedija, Pro Mente, 2010. 


\section{POSTUPANJE U KRIZNIM SITUACIJAMA-KADA, KAKO I ZAS̆TO}

Iako je zdravstvo kao uslužna djelatnost i poziv posebno posvećen brizi za bolesne, statistike pokazuju da se i u tom segmentu događaju neželjeni, pa i nasilni incidenti. U svijetu rada često se spominje apsentizam radnika uvjetovan nasilnim događajima na poslu. U tome posebno prednjači zdravstveni sustav. Prema službenim statistikama u 2013. godini u Sjedinjenim Američkim Državama od svih ozbiljnih nasilnih incidenata u zdravstvenom sektoru (ambulantna zdravstvena skrb, stacionarna zdravstvena skrb i zdravstvena skrb u domovima za starije, nemoćne i dr.), koji su doveli do spriječenosti za rad, čak $80 \%$ se dogodilo u interakciji s pacijentima. Ostali incidenti su uključivali posjetitelje, suradnike i druge. Nešto manje od polovice incidenata uzrokovano je nenamjerno (pri premještanju ili sputavanju) ili bez poznate namjere, a najveća stopa ozljeda uzrokovanih nasiljem s posljedičnim odsustvom s posla događa se u psihijatrijskom okruženju. ${ }^{26}$ Iako u istraživanjima nedostaju relevantne procjene psihičkog stanja bolesnika u danom momentu, ocjena okolinskih precipitirajućih čimbenika, sposobnosti i kompetencija zdravstvenih i drugih profesionalaca u zdravstvu, moguće je promišljati da su specifične situacije dovele do takvih promjena psihičkog stanja u kojima bolesnik nije mogao upravljati svojom agresijom.

Prisila je negativno iskustvo za svako ljudsko biće, i ne samo da se njome krše ljudska prava na slobodan izbor, nego je ona, etički gledano, i povreda prava na autonomiju, osobne izbore ili pak utječe da ljudi djeluju ili iskuse nešto što ne žele.

Prva mjera kod postupanja s osobom, tj. bolesnikom u krizi je deeskalacijski postupak, odnosno korištenje odgovarajućih verbalnih i neverbalnih komunikacijskih vještina. Time se uz izražavanje empatije, terapijskog dogovora i postavljanja granica ponašanja, uz uvažavanje dostojanstva bolesnika nastoji pomoći bolesniku da poveća kapacitet kontrole nad vlastitim agresivnim ponašanjem. Ako je nemoguće uspostavljanje dijaloga, a ponašanje postaje prijeteće, tada se, radi zaštite zdravlja i sigurnosti bolesnika i okoline pristupa korištenju mjera prisile, dakle aktivnostima kojima se ograničava sloboda pojedincu i onemogućava ga da počini bilo kakvu štetu sebi ili drugome. Miran i aktivan dijalog u situaciji primjene mjere prisile, može doprinijeti smirivanju bolesnika. ${ }^{27}$

Osjetljivost ovog područja velika je i u domeni medicinske struke i cilja primum non nocere i u domeni ljudskih prava i sloboda i njihove ugroze, osobito u situacijama ako se radi o osobama $\mathrm{s}$ duševnim smetnjama, kada bi prema svim međunarodnim standardima o suspendiranju tih prava trebalo vrlo obzirno humano i kompetentno odlučivati.

Kao što je prethodno spomenuto, prisila se primjenjuje samo i isključivo u

26 Occupational Safety and Health Administration (OSHA) 2015. Workplace Violence in Healthcare: Understanding the Challenge. https://www.osha.gov/Publications/OSHA3826.pdf, 21. kolovoz 2017.

27 Meehan, T., McIntosh, V., Bergen, H., Aggressive behaviour in the high-secure forensic setting: the perceptions of patients, Journal of Psychiatric and Mental Health Nursing, vol. 13., br. 1., 2006., str. 19-25. 
onim situacijama kada je život i zdravlje osobe te drugih ljudi neposredno ugroženo. Ne postoje jedinstveni kriteriji koji bi ujedno bili i temelj jedinstvenog postupanja prema osobama s duševnim smetnjama, posebice u situacijama potrebe za prisilom. Mogućnost predikcije često je kompleksna i opterećena brojnim čimbenicima, statičkim, dinamičkim i situacijskim, koji se često međusobno preklapaju i imaju relativno malu stabilnu prediktivnost ${ }^{28,29}$, a etički su dvojbeni lažno pozitivni, odnosno lažno negativni rezultati dobiveni na istraživanim skupinama ispitanika. Rizik se također višestruko povećava u stanjima akutne intoksikacije opojnim supstancama. ${ }^{30,31}$

Kada su prepoznatljivi stabilni čimbenici opasnosti od nasilnog ponašanja te $s$ tim u vezi prijeteća ugroza osobe ili okoline, bilo bi korisno ponuditi odgovarajući tretman skupini osoba s visokim rizikom za nasilno ponašanje, što ima svoja bitna ograničenja jer zadire u autonomiju pojedinca i prejudicira ponašanja koja se ne moraju nužno i ostvariti.

Svaka intervencija prema osobama s duševnim smetnjama, koje su posebno ranjive i u podređenom položaju, mora imati svoje medicinsko i sigurnosno opravdanje, a ako se postupa protivno toj nužnosti, tada se postupak smatra nečovječnim i ponižavajućim. Praksa Europskog suda za ljudska prava je u tom svjetlu donijela brojne presude u korist pojedinaca, a protiv države. ${ }^{32,33}$ Izbor profesionalaca treba, uvijek kada je moguće, biti odgovarajuća komunikacija za prevladavanje krizne situacije. ${ }^{34}$ Kvalitetni programi liječenja, smanjenje trajanja hospitalizacije, naglasak na preventivnim aktivnostima i izvaninstitucionalnoj skrbi za duševno oboljele važan su doprinos njihovoj kvaliteti života. S druge strane, rastuće socijalne razlike i društveni događaji koji marginaliziraju ranjive skupine i pojačavaju njihovu socijalnu nesigurnost i isključenost mogu posredno biti prediktor nasilnog ponašanja.

Situacija kada je intervencija nužna zasigurno se može definirati stresnom, nelagodnom i psihički opterećujućom za sve sudionike. Stoga je opravdano primijeniti sve druge metode koje mogu dovesti do smanjivanja napetosti i deeskalacije konflikta, ako se dogodio i redukcije neposredne i životno ugrožavajuće opasnosti po sebe i okolinu. ${ }^{35}$ Iako na ovakva ponašanja upućuju brojne konvencije i propisi kojih se nužno treba pridržavati, krizne situacije prati emocija straha od životne ugroze koja se

28 Szmukler, G., Appelbaum, P. S., Treatment pressures, leverage, coercion, and compulsion in mental health care, Journal of Mental Health, vol. 17., br. 3., 2008., str. 233-244.

29 Norko, M. A., Baranoski, M. V., The Prediction of Violence; Detection of Dangerousness, Brief Treatment and Crisis Intervention, vol. 8., br. 1., 2008., str. 73-91.

30 Dolan, M., Doyle, M., Violence risk prediction. Clinical and actuarial measures and the role of the Psychopathy Checklist, British Journal of Psychiatry, , vol. 177., 2000., str. 303-11.

31 Šendula Jengić, V., Kriminogene specifičnosti psihotičnih počinitelja kaznenih djela: (doktorska disertacija), Zagreb, Medicinski fakultet Sveučilišta u Zagrebu, 2008.

32 Bureš protiv Češke, zahtjev br. 37679/08, 18. listopada 2012. <http://hudoc.echr.coe.int/ eng? $\mathrm{i}=001-113812>$

33 M. S. protiv Hrvatske br. 2., zahtjev br. 75450/12, 19. veljače 2015. < https://uredzastupnika. gov.hr/UserDocsImages//arhiva//M.\%20S.,\%20presuda\%20(final).pdf $>$

34 Bonnet, S. et al., Insight et dangerosité psychiatrique : revue de la littérature, L'Encéphale, vol. 43., br. 2., 2017., str. 146-53.

35 Perlin, M., International human rights and mental disability law: When the silenced are heard, New York, NY, Oxford University Press, 2011. 
javlja kao svjesna reakcija na realnu (netko nas napada) ili očekivanu opasnost.

Osoblje koje radi na psihijatrijskim odjelima ili hitnim prijemima najčešće intervenira prema osobama u kriznom stanju (stanje akutne psihotičnosti, intoksikacije, tjelesno stanje ili stanja koja izazivaju promjene svijesti i afekta, boli, prisustvo, tzv. „tragičnog trijasa“ kao uvoda u autodestruktivno i suicidalno ponašanje, itd.). Sva navedena stanja zahtijevaju intervenciju tek kada ponašanje osobe postaje opasnost po sebe ili okolinu. Svaka intervencija koja uključuje korištenje prisile prema čovjeku, osim što mora imati svoje egzistencijalno sigurnosno i terapijsko opravdanje, mora proizvesti najmanju moguću štetu po duševni i tjelesni integritet osobe nad kojom se prisila vrši, ali i svih sudionika u postupanju uz poštovanje zakonskih normi i visokih etičkih načela.

Ova su postupanja nešto bolje razrađena u forenzičko-psihijatrijskoj praksi te je poznata slijednost pojedinih postupanja, na način ograničavanja sloboda u situacijama kada drugi terapijski postupci ne daju rezultat. U svakodnevnoj psihijatrijskoj praksi kliničari u danom trenutku moraju procijeniti je li rizično ponašanje pacijenta odraz mentalnog poremećaja ili njegovih stvarnih loših namjera. To intrigantno pitanje mad or bad tema je mnogih filozofskih, pravnih i medicinskih rasprava. ${ }^{36,37}$

\section{PRIMJERI IZ PRAKSE}

Unatoč pozitivnim propisima i konvencijama o ljudskim pravima, osobito pravima ranjivih skupina, infrastruktura u psihijatrijskim ustanovama i odjelima, opremljenost i kadrovski potencijali zaostaju za onima u općoj medicini. Međutim, u suvremenoj psihijatriji sve su češći primjeri dobre prakse u postupanju i liječenju duševno oboljelih vidljivi su i pozitivni pomaci. Primjer iz skorije povijesti je Domovinski rat, kada je na psihijatrijske odjele mnogih ustanova pristigao veliki broj psihotično dekompenziranih, agitiranih i suicidalnih bolesnika iz ratom razrušenih bolnica, a kada je zbog nedostatka lijekova, pogotovo najučinkovitijih lijekova, metoda sputavanja u akutnoj kriznoj situaciji, čak i vrlo kratko vrijeme, gotovo bila metoda izbora.

Psihijatrijska bolnica Rab bila je u grupi ustanova koje su tijekom Domovinskog rata primile velik broj akutnih bolesnika iz ratom razrušenih područja, ali i raznih institucija i domova za duševno oboljele koji su bili ratom pogođeni (Zemunik, Gospić, itd.). Ratna iskustva bila su dodatni poticaj na kvalitetniju i kontinuiranu izobrazbu kadra. Odgovornost za takva postupanja ipak nije bila samo u ratnim događanjima nego i mnogo šira. Odnosila se na nedostatan broj, ali i psihoterapijsku edukaciju osoblja, usmjerenu na razvijanje komunikacijskih vještina, krizne i terapijske komunikacije itd. Unatoč relativnom manjku kadra, kontinuirana edukacija osoblja smanjila je broj i vrstu prisilnih intervencija. Dugogodišnjom edukacijom svih profila zdravstvenih radnika i poboljšanjem uvjeta rada, terapijskih programa i boravka bolesnika

36 Appelbaum, P. S., Ethics in evolution: The incompatibility of clinical and forensic functions, American Journal of Psychiatry, vol. 154., 1997., str. 445-446.

37 Höffler, K., Stadtland, C., Mad or bad? Der Begriff "psychische Störung” des ThUG im Lichte der Rechtsprechung des BVerfG und des EGMR. Strafverteidiger, vol. 4., 2012., str. 239-246. 
uvelike se poboljšala terapijska klima i smanjio broj kriznih intervencija. Empatija, profesionalni odnos, sposobnost i umijeće komunikacijskih vještina, razumijevanje bolesnikovih potreba, prepoznavanje iracionalnog i psihopatološkog zasigurno bi smanjili prekomjerne i neopravdane intervencije, ali i spriječili situacije koje su zbog izostanka pravodobne i odgovarajuće intervencije rezultirale ugrožavanjem zdravlja i života bolesnika i/ili okoline.

Unaprjeđenje kvalitete rada mora se temeljiti na odgovornoj procjeni stanja, jasnim nedvojbenim algoritmima aktivnosti, timskom i dobro definiranom postupanju uz poštovanje najviših postulata etike i medicinske struke.

Aktivnosti i postupanja profesionalaca u kriznim situacijama smiju imati ograničeno trajanje, tj. onoliko koliko traje potreba. Procjena i odgovornost za intervenciju je na psihijatru - voditelju tima.

Stigma, stavovi društva, nedostupnost ili nedovoljno poznavanje učinkovitih metoda liječenja duševno bolesnih može imati za posljedicu neučinkoviti način neutralizacije potencijalno ili stvarno opasnog ponašanja psihičkog stanja pojedinca, ali i moguće pogrešne intervencije zdravstvenih djelatnika, bilo nepotrebne ili zakašnjele, ako bi procjena bila pogrešna.

U psihijatrijskom okruženju mjere prisile mogu biti korištene u tri situacije. Iako one u praktičnom smislu nemaju svoja jasna razgraničenja, mogu se koristiti kada je:

a) nužno ograničiti pacijentovu slobodu na neko određeno vrijeme kako bi se preveniralo njegovo nasilno ponašanje i ozljeđivanje sebe $\mathrm{i} / \mathrm{ili}$ drugih,

b) za prisilu bolesnika koji odbija tretman ili nema uvida da bi na isti pristao, pri čemu je nedvojbeno utvrđena iminentna opasnost po sebe i okolinu

c) u kratkotrajnim situacijama u kojima postoji visoka vjerojatnost nasilnog ponašanja bolesnika.

Prisilne mjere u psihijatriji subordinirane su čitavom nizu zakona i pravnih pravila. Ograničenje uporabe sile posebno se ističe u UN-ovoj Konvenciji protiv mučenja i drugih okrutnih, neljudskih ili ponižavajućih postupaka i kažnjavanja iz 1987., Međunarodnom paktu o građanskim i političkim pravima iz 1966. godine, Konvenciji za zaštitu ljudskih prava i temeljnih sloboda iz 1953. Europski odbor za sprječavanje mučenja i neljudskog ili ponižavajućeg postupanja ili kažnjavanja (CPT) posebno proučava sve mjere prisilnog postupanja prema osobama u psihijatrijskim ustanovama. ${ }^{38}$ Njegovi predstavnici više su puta boravili i u Republici Hrvatskoj, vršili izvide u ustanovama i o tome dali svoja pisana izvješća koja su objavljena i na službenim mrežnim stranicama. Psihijatrijska bolnica Rab bila je među rijetkim zdravstvenim ustanovama koja je, upravo zbog kvalitete rada i odnosa prema bolesnicima te vrlo malog broja prisilnih intervencija, dobila pozitivnu ocjenu. ${ }^{39}$

Nespornaječinjenica da unašoj zemlji općenito uvjeti smještajailiječenja duševno oboljelih godinama zaostaju u odnosu na ostale medicinske odjele. Isto se odnosi na broj i ekipiranost kadra te financiranje. Psihijatrija u zajednici kao orijentacijska

38 Finzen, A., Haug, J.-J., Beck, A., Lüthy, D., Hilfe wider Willen. Zwangsmedikation im psychiatrischen Alltag, Psychiatrie Verlag, Bonn, 1993.

39 Report to the Croatian Government on the visit to Croatia carried out by the European Committee for the Prevention of Torture and Inhuman or Degrading Treatment or Punishment (CPT) from 4 to 14 May 2007, <https://rm.coe.int/1680695561>, 20. kolovoz 2017. 
strategija u Europskoj uniji i šire s deinstitucionalizacijom dobro je rješenje za veći broj duševno oboljelih, ali zahtijeva ciljane programe kao i dodatne materijalne i ljudske resurse. Inicijativa za bolju zaštitu prava pacijenata, bolje uvjete i standarde u smještaju i postupanju s osobama s duševnim smetnjama pokrenuta je na nizu razina: od samih psihijatrijskih ustanova, psihijatrijskih društava, pravobraniteljstva, osobito pravobranitelja za zaštitu osoba s invaliditetom, pa do nacionalnih strategija. Jedna je od strategija i Nacionalni preventivni mehanizam, o čemu redovito podnosi izvješće pučki pravobranitelj. Pokrenuta je inicijativa i za doradu Zakona o zaštiti osoba s duševnim smetnjama (ZZODS), koji je kao novi zakon stupio na snagu 1. siječnja 2015. te su bitno ojačana prava i stvoreni preduvjeti za bolju zaštitu osoba s duševnim smetnjama. U tom je smislu Hrvatski liječnički zbor zajedno s Hrvatskim društvom za kliničku psihijatriju, Hrvatskim društvom za forenzičku psihijatriju te Hrvatskim psihijatrijskim društvom, uz podršku Psihijatrijskog društva medicinskih sestara i tehničara HUMS RH, donio Strategiju prevencije agresivnog ponašanja uz smjernice za prevenciju agresivnog ponašanja i primjenu mjera prisile u području psihijatrije 2016. godine. ${ }^{40}$ Dokument je donio preporuke za postupke s agresivnim pacijentom, ponašanje osoblja i uređenje terapijske okoline. Temeljem Pravilnika o vrstama i načinu primjene mjera prisile prema osobi s težim duševnim smetnjama, ${ }^{41}$ sve psihijatrijske službe moraju imati strategiju prevencije agresivnog ponašanja kao i pisane upute o pravilima postupanja radnika prije, tijekom i nakon primjene mjera prisile kod agresivnog ponašanja pacijenta. Posebna pažnja pridaje se i, tzv. prijemnim ambulantama za intervju s rizičnim pacijentom, sustavu signaliziranja i alarmnom sustavu te edukaciji osoblja. Nužno je napomenuti da je kontinuirana edukacija i izobrazba osoblja jedan od temeljnih čimbenika za kvalitetu liječenja, s obzirom na nužnost razumijevanja uzroka agresivnog ponašanja svakog pojedinog bolesnika i na tome treba kontinuirano raditi. Tek identificiranjem uzroka agresivnog ponašanja $u$ kliničkoj situaciji može se osigurati adekvatni postupak njegove prevencije i kontrole

\section{ZAKLJUČNA RAZMATRANJA}

Unatoč čitavom nizu istraživanja, primjena prisile u postupanju prema osobama s duševnim smetnjama klinička praksa češće počiva na nacionalnim ili lokalnim okvirima postupanja (regionalnim ili institucionalnim) nego na znanstvenoj utemeljenosti. ${ }^{42}$ Mobilni psihijatrijski timovi, hitni prijemi, psihijatrijski odjeli općih i specijalnih bolnica, posebice forenzički psihijatrijski odjeli, na određeni su način dio socijalne mreže u kojoj je važan čimbenik terapijski odnos osoblja i bolesnika, ali i izbor i odnos društva prema oboljelima. I na terapijskom odnosu i na odnosu društva prema oboljelima nužno je raditi. Često je rad na sebi najteži i u pravilu izaziva ambivalenciju. Adekvatan terapijski pristup i razumijevanje kod mjera prisile

40 Dokument dostupan na: <http:/www.psihijatrija.hr/site/wp-content/uploads/2017/03/ strategijaprevencijeagresivnostFF.pdf> 20. kolovoz 2017.

41 Narodne novine, br. 15/2016.

42 Kalisova, L., et al., Do patient and ward-related characteristics influence the use of coercive measures? Results from the EUNOMIA international study, Social Psychiatry and Psychiatric Epidemiology, vol. 49., br. 10., 2014., str. 1619-1629. 
mogu paradoksalno povećati slobodu volje, misli, akcija i suradnje. ${ }^{43}$ Nadalje, metoda primjene bilo koje vrste sputavanja, ograničavanja i prisile kao disciplinske mjere terapijski je krajnje upitna i sve češće se napušta. ${ }^{44}$

Sa sociološke perspektive česti su polarizirajući stavovi oko rješavanja pojedinih problema bolesnika, koji mogu biti i nepomirljivi kada je, sociološki gledano, medicina samo pasivno postupanje, dok s medicinskog aspekta široki sociološki pristup može biti opasan kada se radi o neposrednoj opasnosti po sebe i okolinu. Stoga sociološka perspektiva prisilnih mjera ne može biti izolirana od psihijatrije, kao neovisan fenomen. Interpersonalna dinamika može bitno utjecati na terapijski odnos $\mathrm{i}$ ishod samog liječenja s jedne strane, dok situacija prisile, čak i kada formalno nije definirana prisilnom mjerom, zahvaća osobni i širi kontekst, kao i osobne stavove i odnose pojedinaca. ${ }^{45}$

Zaključno je nužno spomenuti da su, nažalost, neželjeni događaji mogući i da postoji dihotomija između znanstvene, kliničke i etičke kompetencije. Najveća medicinska stručnost ne mora značiti najveću etičku stručnost. U društvenom kontekstu također je puno čimbenika koji utječu na postupanja i prisilu koji se odnose na materijalne mogućnosti i normative, kadrovske resurse $i$ edukaciju što pripada domeni zdravstvenih politika, jer i najsveobuhvatnija politika ne jamči socijalnu pravednost. Etičke dvojbe i dihotomija između dužnosti liječnika i autonomije bolesnika očituje se u činjenici da najveća moguća svijest i odgovornost o dužnostima liječnika i zdravstvenih djelatnika ne jamči najoptimalnije postupanje i uvažavanje autonomije bolesnika. Zbog toga je važno uvažiti ova načela da se ne učini šteta veća od imanentne. Izvrsna psihijatrijska praksa značila bi uspostavu optimalne ravnoteže potreba pojedinca i okoline pri čemu je važna bila i uspostava najviših stručnih i etičkih standarda postupanja.

Kreiranje socijalne, političke i opće društvene klime koja svakom pojedincu jamči ostvarivanje njegovih ustavnih i građanskih prava dostupnosti i kvalitete zdravstvene zaštite zasigurno bi doprinijelo izostanku ili bar manjem kršenju tih prava oboljelih pojedinaca, kao i nastavno primjene sile zdravstvenih profesionalaca i drugih subjekata uključenih u proces prisile.

43 Adshead, G., Davies, T., Wise Restraints: Ethical Issues in the Coercion of Forensic Patients, u: Völlm, B., Nedopil, N. (ur.), The Use of Coercive Measures in Forensic Psychiatric Care. Legal, Ethical and Practical Challenges, Cham, Springer, 2016.

44 Lindemann, M., Anmerkung Oberlandesgericht Hamburg, Unzula“ssigkeit von Disziplinarmaßnahmen ohne Gesetzesgrundlage, Recht \& Psychiatrie, vol. 25., br. 4., 2007., str. 203-206.

45 Middleton, H., Sociological Perspectives of Coercion in Psychiatry. u: Völlm, B., Nedopil, N. (ur.), The Use of Coercive Measures in Forensic Psychiatric Care. Legal, Ethical and Practical Challenges, Springer, 2016. 


\section{LITERATURA}

1. Adshead, G., Davies, T., Wise Restraints: Ethical Issues in the Coercion of Forensic Patients, u: Völlm, B., Nedopil, N. (ur.), The Use of Coercive Measures in Forensic Psychiatric Care. Legal, Ethical and Practical Challenges, Springer, 2016.

2. Appelbaum, P. S., Ethics in evolution: The incompatibility of clinical and forensic functions, American Journal of Psychiatry, vol. 154., 1997., str. 445-446.

3. Bonnet, S. et al., Insight et dangerosité psychiatrique : revue de la littérature, L'Encéphale, vol. 43., br. 2., 2017., str. 146-53.

4. Bureš protiv Češke, zahtjev br. 37679/08, 18. listopada 2012., <http://hudoc.echr.coe.int/ eng?i=001-113812>, 20. kolovoz 2017.

5. Davidson, R. J., et al., Dysfunction in the Neural Circuitry of Emotion Regulation - A Possible Prelude to Violence, Science, vol. 289., br. 5476., 2000., str. 591-94.

6. Dekker, JM., et al., Victimization of patients with severe psychiatric disorders: prevalence, risk factors, protective factors and consequences for mental health. A longitudinal study, BMC Public Health, vol. 10., br. 1., 2010., str. 687.

7. Strategije prevencije agresivnog ponašanja, <http://www.psihijatrija.hr/site/wp-content/ uploads/2017/03/strategijaprevencijeagresivnostFF.pdf $>20$. kolovoz 2017.

8. Dolan, M., Doyle, M., Violence risk prediction. Clinical and actuarial measures and the role of the Psychopathy Checklist, British Journal of Psychiatry, vol. 177., 2000., str. 303-11.

9. Farrington, D. P., Origins of Violent Behavior Over the Life Span (poglavlje 2.), u: Flannery, D. J. et al., The Cambridge Handbook of Violent Behavior and Aggression, Cambridge, Cambridge University Press, 2007.

10. Finzen, A., Haug, J.-J., Beck, A., Lüthy, D., Hilfe wider Willen. Zwangsmedikation im psychiatrischen Alltag, Psychiatrie Verlag, Bonn, 1993.

11. Frankle, W. G., et al., Brain Serotonin Transporter Distribution in Subjects With Impulsive Aggressivity: A Positron Emission Study With [ $11 \mathrm{C}] \mathrm{McN}$ 5652, American Journal of Psychiatry, vol. 162., br. 5., 2005., str. 915-23.

12. Friedman, Richard A, Violence and Mental Illness - How Strong is the Link?, New England Journal of Medicine, vol. 355., br. 20., 2006., str. 2064-66.

13. Fromm, E., The anatomy of human destructiveness, New York, Holt, Rinehart and Winston, 1973.

14. Hiday, V. A., et al., Criminal Victimization of Persons With Severe Mental Illness, Psychiatric Services, vol. 50., br. 1., 1999., str. 62-68.

15. Hiday, V. A., The Social Context of Mental Illness and Violence, Journal of Health and Social Behavior, vol. 36., br. 2., 1995., str. 122-37.

16. Höffler, K., Stadtland, C., Mad or bad? Der Begriff "psychische Störung" des ThUG im Lichte der Rechtsprechung des BVerfG und des EGMR. Strafverteidiger, vol. 4., 2012., str. 239-246.

17. Horwitz, A. V., The Logic of Social Control, New York, Plenum Press, 1990.

18. Jaeger, M., et al., Informal coercion in acute inpatient setting - knowledge and attitudes held by mental health professionals, Psychiatric Research, vol. 220., br. 3., 2014., str. 1007-1011.

19. Kalisova, L., et al., Do patient and ward-related characteristics influence the use of coercive measures? Results from the EUNOMIA international study, Social Psychiatry and Psychiatric Epidemiology, vol. 49., br. 10., 2014., str. 1619-1629.

20. Lindemann, M., Anmerkung Oberlandesgericht Hamburg, Unzula"ssigkeit von Disziplinarmaßnahmen ohne Gesetzesgrundlage, Recht \& Psychiatrie, vol. 25., br. 4., 2007., str. 203-206.

21. M. S. protiv Hrvatske br. 2., zahtjev br. 75450/12, 19. veljače 2015. <https:// uredzastupnika.gov.hr/UserDocsImages//arhiva//M.\%20S.,\%20presuda\%20(final).pdf $>$ 
22. Maniglio, R., Severe mental illness and criminal victimization: a systematic review, Acta Psychiatrica Scandinavica, vol. 119., br. 3., 2009., str. 180-91.

23. Margetić, L., Opća povijest prava i države, Rijeka, Pravni fakultet Sveučilišta, Rijeka, 1998.

24. Marzuk, P. M., Violence, Crime, and Mental Illness, Archives of General Psychiatry, vol. 53., br. 6., 1996., str. 481-6.

25. Mattson, M. P. (ur.), Neurobiology of Aggression, Understanding and Preventing Violence, Totowa, New Jersey, Humana Press, 2003.

26. Meehan, T., McIntosh, V., Bergen, H., Aggressive behaviour in the high-secure forensic setting: the perceptions of patients, Journal of Psychiatric and Mental Health Nursing, vol. 13., br. 1., 2006., str. 19-25.

27. Middleton, H., Sociological Perspectives of Coercion in Psychiatry. u: Völlm, B., Nedopil, N. (ur.), The Use of Coercive Measures in Forensic Psychiatric Care. Legal, Ethical and Practical Challenges, Cham, Springer, 2016.

28. Newton-Howes, G., Coercion in psychiatric care: where are we now, what do we know, where do we go?, The Psychiatrist, vol. 34., br. 6., 2010., str. 217-20.

29. Norko, M. A., Baranoski, M. V., The Prediction of Violence; Detection of Dangerousness, Brief Treatment and Crisis Intervention, vol. 8., br. 1., 2008., str. 73-91.

30. Occupational Safety and Health Administration (OSHA) 2015. Workplace Violence in Healthcare: Understanding the Challenge. https:/www.osha.gov/Publications/ OSHA3826.pdf, 21. kolovoz 2017.

31. Patrick, C. J., Psychophysiological correlates of aggression and violence: an integrative review, Philosophical Transactions of the Royal Society B: Biological Sciences, vol. 363., br. 1503., 2008., str. 2543-55.

32. Perlin, M., International human rights and mental disability law: When the silenced are heard, New York, NY, Oxford University Press, 2011.

33. Peršić, N., Peršić-Brida, M., Povijesni razvoj psihijatrije, Socijalna psihijatrija, vol. 18., 1990., str. 237-281.

34. Pravilnik o vrstama i načinu primjene mjera prisile prema osobi s težim duševnim smetnjama, Narodne novine, br. 16/2015.

35. Report to the Croatian Government on the visit to Croatia carried out by the European Committee for the Prevention of Torture and Inhuman or Degrading Treatment or Punishment (CPT) from 4 to 14 May 2007, <https://rm.coe.int/1680695561>, 20. kolovoz 2017.

36. Rueve, M. E., Welton, R. S., Violence and Mental Illness, Psychiatry, vol. 5., br. 5., 2008. str. 34-48.

37. Sartorius, N., Borba za duševno zdravlje, Zagreb, Profil multimedija, Pro Mente, 2010.

38. Szmukler, G., Appelbaum, P. S., Treatment pressures, leverage, coercion, and compulsion in mental health care, Journal of Mental Health, vol. 17., br. 3., 2008., str. 233-244.

39. Šendula Jengić, V., Kriminogene specifičnosti psihotičnih počinitelja kaznenih djela: (doktorska disertacija), Zagreb, Medicinski fakultet Sveučilišta u Zagrebu, 2008.

40. Šendula-Jengić, V., Bošković, G., Forenzički značaj drugih, težih duševnih smetnji, Zbornik Pravnog fakulteta Sveučilišta u Rijeci, vol. 22., br. 2., 2001., str. 635-654.

41. Šendula-Jengić, V., Juretić, I., Hodak, J., Psychiatric hospital: from asylums to centres for mind-body wellness, Collegium antropologicum, vol. 35., br. 4., 2011., str. 979-88.

42. Van Elst, L. T., et al., Trimble, Affective aggression in patients with temporal lobe epilepsy: A quantitative MRI study of the amygdala, Brain, vol. 123., br. 2.,2000., str. 234-43.

43. Wynn, R., Psychiatric inpatients' experiences with restraint, Journal of Forensic Psychiatry \& Psychology, vol. 15., br. 1., 2004., str. 124-44.

44. Zakon o zaštiti osoba s duševnim smetnjama, Narodne novine 76/2014 


\section{Vesna Šendula Jengić $*$}

Sanja Katalinić**

Summary

\section{CRISIS SITUATIONS AND THE USE OF COERCION IN PSYCHIATRY}

The article deals with phenomena of aggression and violence in humans with special attention to mental illnesses. Crisis and violent behaviour do not occur only in psychiatry. It can happen in any context or circumstance, and any person could either fall victim or be the perpetrator. Knowledge of multicausality and complexity as well as of individual environmental and situational factors that can lead to violent behaviour has little power of prediction. Statistical indicators can conceal false positive and false negative results, whereby the error of assessment can dramatically increase the risk of some behaviour or lead to an unjustified suspension of human rights of freedom.

The use of coercion in psychiatry is necessary only in exceptional situations where dangerous behaviour directly threatens the life and health of the person or the environment or property.

Positive legislation, in particular the Law on the Protection of Persons with Mental Disabilities (Narodne novine 76/2014) and the Ordinance on the Types and Methods of Enforcement of Coercion to a Person with Serious Mental Disorders (Narodne novine 16/2015) further protects the rights of the mentally ill and prescribes the type and mode of coercion as well as procedures for handling. Professional psychiatric societies have provided additional guidelines and treatment strategies.

The paper emphasizes the need for better conditions, infrastructure and human resources, with continuous improvement and evaluation of the quality of work in psychiatry. In conclusion, the standards and ethical issues of society and a broad spectrum of activities are being discussed, from destigmatization, through better access to services to standards of living and social inclusion, which can indirectly lead to a significant reduction of violence in society.

Keywords: aggressive behaviour, coercion, human rights, Rab Psychiatric Hospital.

* Vesna Šendula Jengić, MD, Ph. D., Associate Professor, Faculty of Medicine, University of Rijeka, CEO General Psychiatric Hospital Rab; vesna.sendula@gmail.com

** Sanja Katalinić, MD, Ph. D., Psychiatrist, Head of Department for Social Psychiatry General Psychiatric Hospital Rab; katalinic69@yahoo.com 


\section{Zussamenfassung}

\section{KRISENZUSTÄNDE UND ANWENDUNG VON ZWANGSMASSNAHMEN IN DER PSYCHIATRIE}

In der Arbeit wird über die Phänomene der Aggressivität und Gewalt bei Menschen diskutiert, wobei man besonderen Wert auf die Personen mit seelischen Störungen legt. Krisenzustände und Gewaltverhalten gibt es nicht nur in der Psychiatrie. Es kann immer zu einem solchem Zustand und Verhalten kommen und jeder kann unter bestimmten Umständen sowohl Opfer als auch Täter sein. Multikausalität und Komplexität sowie auch individuelle Umstände und situationsbezogene Faktoren, welche zum Gewaltverhalten führen können, haben nur geringen Prognosekraft. Statistische Indikatoren andererseits können falsch positive und falsch negative Ergebnisse verbergen, wobei ein Fehler in der Einschätzung das Risiko zum Erscheinen eines Verhaltens drastisch erhöhen oder zum unrechtfertigten Entziehung der Freiheit führen kann.

Zwangsmaßnahmen in der Psychiatrie sind nur ausnahmsweise anzuwenden, und zwar, wenn ein gefährliches Verhalten direkt das Leben und die Gesundheit einer Person oder einer Umgebung gefährdet. Darüber hinaus ist die Dauer von Zwangsmaßnahmen auch beschränkt.

Die Gesetzesregulative, insbesondere das Gesetz über den Schutz von Personen mit seelischen Störungen (Amtsblatt der Republik Kroatien Nr. 76/2014) und die Ordnung über die Arten und die Weise der Anwendung von Zwangsmaßnahmen gegenüber den Personen mit schwierigen seelischen Störungen (Amtsblatt der Republik Kroatien Nr. 16/2015), dient als zusätzlicher Schutz der Rechte dieser Patientengruppe und schreibt die Arten und die Weise der Anwendung von Zwangsmaßnahmen sowie auch die Vorgehensweise. Zusätzliche Richtlinien und Vorgehensstrategien wurden auch von den Gesellschaften für Psychiatrie gegeben.

In der Arbeit wird betont, dass bessere Bedingungen, Infrastruktur und Arbeitskräfte sowie auch ständige Entwicklung und Bewertung der Arbeitsqualität in der Psychiatrie erforderlich sind. Abschließend werden Standards und ethische Fragen in Betracht gezogen, wie zum Beispiel Destigmatisierung, besserer Zugang zu den Diensten, Lebensstandard und soziale Inklusion. Es wird die Ansicht vertreten, dass diese Fragen das Gewaltverhalten in der Gesellschaft vermindern können.

Schlüsselwörter: aggressives Verhalten, Zwang, Menschenrechte, Psychiatrisches Krankenhaus Rab. 
Riassunto

\section{STATI DI CRISI E USO DI MISURE COERCITIVE IN PSICHIATRIA}

Nell'articolo si dibatte dei fenomeni di aggressività e violenza presenti nell'uomo, con particolare attenzione per coloro che sono affetti da disturbi mentali. Lo stato di crisi ed il comportamento violento non capitano soltanto in psichiatria. Ciò può capitare sempre: la vittima, come pure l'autore, può in date circostanze essere chiunque. La conoscenza delle molteplici causalità e della complessità, così come dei fattori individuali circostanziali, i quali possono condurre a comportamenti violenti, hanno una limitata portata predittiva. Gli indicatori statistici possono celare risultati positivamente o negativamente falsati, sicché l'errore di valutazione può elevare drasticamente il rischio che un certo comportamento avvenga o addirittura che conduca ad una ingiustificata sospensione della libertà personale dell'uomo.

L'uso della costrizione in psichiatria è necessaria soltanto in casi eccezionali e per una durata limitata, quando mediante un comportamento pericoloso si possa direttamente mettere in rischio la vita o la salute delle persone.

La normativa vigente, in particolare la Legge sulla protezione delle persone con disturbi mentali (NN 76/2014) ed il Regolamento sui tipi e le modalità di uso delle misure coercitive nei confronti della persone con disturbi mentali gravi (NN 16/2015) dà ulteriore protezione ai diritti degli infermi e detta i tipi e le modalità di uso della coercizione, come pure le procedure applicative.

Nello scritto si solleva l'esigenza di prevedere condizioni migliori, l'infrastruttura e le risorse umane unitamente ad un continuo miglioramento e ad una valutazione della qualità dell'operato in psichiatria. In conclusione, si valutano gli standard e le questioni etiche della società e l'ampio spettro di attività, partendo dalla destimmatizzazione, attraverso un migliore accesso ai servizi fino agli standard di vita e dell'inclusione sociale, che indirettamente possono portare ad una rilevante diminuzione della violenza nella società.

Parole chiave: comportamento aggressivo, coercizione, diritti umani, Ospedale psichiatrico di Rab. 